\title{
Non-destructive Analyses of 16th Century Documents
}

\begin{abstract}
LUDMILA MOTELICA, LUMINITA CRACIUN, IOANA ARDELEAN*, MADALINA VIOLETA IOANA
University Politehnica of Bucharest, Faculty of Applied Chemistry and Materials Sciences, 1 Gh. Polizu Str., 011061, Bucharest, Romania

The aim of the present study was to obtain spectral data (FTIR, UV-Vis and fluorescence) from five paper specimens taken from documents made between 1517-1609 that are in the custody of Carol I"Central University Library. The samples were chosen in an effort to characterize and better understand the paper composition and origin in order to have more information to enable comparison and identification with documents from same period. Gelatine content, cellulose type, crystallinity index, degradation degree and presence of calcium (as alkaline reserve) were determined by UV-Vis, FTIR and fluorescence spectrometry.
\end{abstract}

Keywords: handmade paper, non-destructive, gelatine, alum, spectral data

The cultural heritage can be better preserved by increasing the knowledge level about the historical objects by means of advanced chemical and physical analyses. By identification of materials and processes employed at manufacture moment, we can reach back through time and gain a better understanding of technology used and craftsmanship needed.

Whenever there is no papermakers' archives (which are very hard to create and out of reach for most libraries) the historical paper samples themselves can reveal important pieces of information about manufacture process and the impact on paper stability of various ingredients used. Finding ways to decode the hidden messages within the paper is the main challenge for researchers in this domain.

The raw materials for early European paper were the rags (mainly of flax and hemp). The rags were sorted accordingly with finesse and colour, retted, then stamped before arrive to the vat. After the paper forming and drying, the next important step was surface sizing with gelatine or a mix of alum/gelatine. The final addition of gelatine was producing a supple, pliantbutdurable paper. So in the end the paper is a heterogeneous material which main component is cellulose but it also contains important proportions of gelatine and alum. Researchers have found that gelatine is in higher concentration in historical papers in good condition [1].

Cellulose is by no means inert, therefore paper may become brittle. Paper of various qualities was handmade in mills across Europe. The poor quality paperhad inclusions or stray foreign fibres, straw, bits of debris, clumps, and signs of quick or unskilled sheet forming or couching. On the other hand, a fine sheet of paper was made from highquality rag fibre content, with no stray fibres or inclusions, and with an uniform appearance in light. Those who routinely handle historical papers tend to associate browned paper with brittleness or lack of durability and light-coloured sheets with stability or strength [2].

Handmade paper from early European mills was rather weak, soft, and absorbent after drying. To improve the mechanical properties and to make it less absorbent the paper required an application of gelatine size. In addition, to make it look like parchment (the standard support for early books) the sheet was made thicker. The light colour of the finished paper was achieved not only by using fine white rags but also by adding calcium compounds like lime. According to fifteenth- and seventeenth-century accounts, lime was used during beating, probably to help facilitate maceration of the rags by swelling the fibre [35]. The rapid spread of printing and increasing demand for books has probably changed the way paper was looking around 1500 . The quickest way for papermakers to lower the price per sheet was simply to make their paper thinner. Cutting back on other ingredients, such as calcium compounds and gelatine would have also helped lower expenses and therefore the price of the finished paper. Therefore the papers from $15^{\text {th }}$ century are thicker and contain $\sim 10 \%$ gelatine while the papers from $16^{\text {th }}$ century are thinner and contain usually up to $5 \%$ gelatine.

The cellulose is a natural polymer composed by chains of various length obtained from $\beta$-glucose units linked in 14 positions (fig. 1). The degree of polymerization is subject to origin of cellulose and specific treatment during manufacturing.

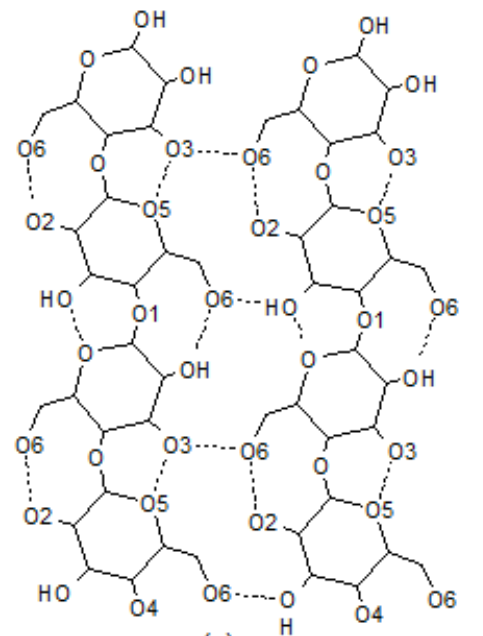

(a)

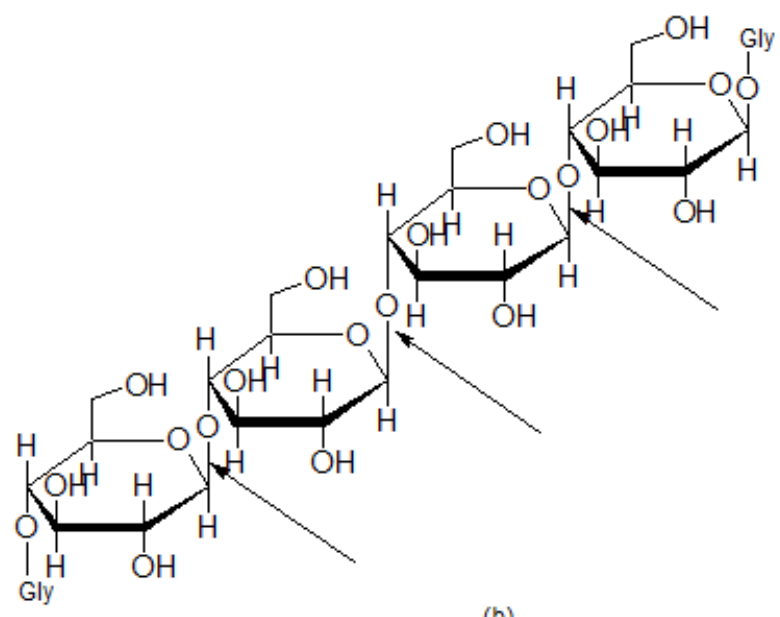

(b)
Fig. 1. The hydrogen bonds intra and inter-chains (a); the structure of cellulose (b) 
Cellulose is a rather straight-line polymer with no branching and the multiple hydroxyl moieties from glucose will form hydrogen bonds intra and inter-chains, holding them firmly side-by-side. Small units of cellulose formed by hydrogen bonding and stacked by van der Waals forces are named elemental fibrils. Some of these fibrils are ordered and form crystalline regions, while others are less ordered and form amorphous regions. Crystalline cellulose is more resistant than amorphous one, therefore one parameter for characterization of cellulose is the crystallinity index.

Elemental fibrils stack to form filaments named microfibrils, while braided microfibrils are forming one fibril, and many fibrils gathered together form a fibre.

\section{Experimental part}

The five samples were collected from books that are in the custody of Carol I Central University Library, accordingly with the table 1 data.

\section{Experimental techniques}

a) The FTIR spectra were recorded with a Thermo Scientific Nicolet IS 50 FTIR spectrophotometer with an ATR accessory with a diamond crystal. The recorded spectra were in the form of means of 30 spectra, performed in the 4000-400 $\mathrm{cm}^{-1}$ range with a $4 \mathrm{~cm}^{-1}$ resolution and atmospheric correction switched on at room temperature $\left(25^{\circ} \mathrm{C}\right)$.

b) Photoluminescence spectra. Photoluminescence spectra (PL) were recorded with a Perkin Elmer P55 spectrometer using a Xe lamp as a UV light source at ambient temperature, in the range $350-800 \mathrm{~nm}$. The measurements were made with scan speed of $200 \mathrm{~nm}$. $\mathrm{min}^{-1}$, slit of $10 \mathrm{~nm}$, and cut-off filter of $350 \mathrm{~nm}$. An excitation wavelength of $320 \mathrm{~nm}$ was used.

c) Diffuse reflectance spectra measurements were made with a JASCO V560 spectrophotometer with solid sample accessory, in the domain $200-800 \mathrm{~nm}$, with a speed of $200 \mathrm{~nm} \cdot \mathrm{min}^{-1}$.

\section{Results and discussions}

The FTIR spectra of the five samples are show $n$ in figure 2. The wavenumbers of principal absorption peaks and their assignment are presented in table 2 . The intensity modification for some of these bands can be useful for interpretation of the structural changes in the paper over time. Most of these bands are assigned to the main component of the paper, cellulose. The paper is relative stabile in time, but it can age and can be degraded by chemicals and microorganisms. Most papers suffer deterioration due to endogenous and/or exogenous factors (like low $\mathrm{pH}$, metal ions like $\mathrm{Fe}^{3+}$, lignin, other degradation products respectively heat, humidity, pollutant gases) [68]. Some acidic substances (like alum), oxidizing agents or moist can greatly accelerate the degradation process, shortening the cellulose chains and lowering the crystallinity grade. The oxidizing agents can react with hydroxyl moieties and form ketones, aldehydes or carboxylic acids with absorption bands at $1730 \mathrm{~cm}^{-1}$. As these band is absent in spectra of all samples we can conclude that the paper was stored in good conditions over the centuries.

The FTIR spectra were used to monitor the type of hydrogen bonds in the cellulose. The hydroxyl moieties of $\beta$-D glucose can participate in a large range of hydrogen bonds, both intra and inter-molecular. The cellulose structure can be described on three levels: at molecular level - the structure of a single cellulose macromolecule; at supramolecular level - the ordering and mutual interactions between multiple macromolecular chains; morphological level -where is described the complex architecture of the fibres. In general any degradation process of cellulose starts with hemiacetal bonds (fig. 1b). There are also various reactions that can be performed at each hydroxyl moiety of molecule. The cellulose chains are bonded together by hydrogen bonds, making cellulose a highly hydrophilic molecule, in which trapped water molecules can play an important role. The degree of ordered chains can go up to $80 \%$ forming the crystalline domains, while the rest is the amorphous cellulose.

Deconvolution of the $3000-3500 \mathrm{~cm}^{-1}$ region in FTIR spectra has indicated the presence of absorption bands at $3430,3334,3292$ and $3276 \mathrm{~cm}^{-1}$ corresponding to the intermolecular hydrogen bonds $\mathrm{O}(2) \mathrm{H} . . . \mathrm{O}, \mathrm{O}(3) \mathrm{H} . . . \mathrm{O}$ and intermolecular $\mathrm{O}(6) \mathrm{H} \ldots \mathrm{O}$ and $\mathrm{O} \ldots . . \mathrm{H}$. These are indicating a crystalline structure type $I_{\text {a }}$ (monoclinic) along with amorphous cellulose. In addition the shoulder from 3550 $\mathrm{cm}^{-1}$ indicate the presence of small lignin quantities in samples [16].

The absorption band from $1420-1430 \mathrm{~cm}^{-1}$ is associated with the quantity of crystalline cellulose, while the 899 $\mathrm{cm}^{-1}$ band is corresponding to the amorphous cellulose [17]. The ratio between intensities of 1420 and $899 \mathrm{~cm}^{-1}$ absorption bands is defined as an empirical index, named crystallinity lateral order index (LOI) [18]. The ratio between intensities of absorption bands from 1369 and $2899 \mathrm{~cm}^{-1}$ represents the total crystallinity index (TCI). While the TCl is a measure of crystallinity of cellulose, the $\mathrm{LO}$ I is well correlated with the general degree of ordering inside the cellulose [19]. The results obtained are presented in table 3. For wood cellulose the TCI value usually is around 0.5 and under, while for vegetal fibres cellulose is over 1 . In the same time LOI value is over 2 for cellulose obtained from wood pulp while is around 1 and under for vegetal fibres cellulose.

The $1 \mathrm{~A}$ sample presented the highest values for $\mathrm{TCl}$ and LOI indicating the highest degree of crystallinity and a more ordered cellulose structure, which can indicate better raw materials and craftsmanship, but also proper storage conditions. The lowest value for TCl is found for sample $3 \mathrm{~A}$ while the lowest $\mathrm{LOI}$ value is present at sample $2 \mathrm{~A}$. This indicates that the cellulose from these samples is composed of more amorphous domains when compared with the cellulose from sample $1 \mathrm{~A}$.

\begin{tabular}{|c|c|c|c|c|c|c|}
\hline Sample & Year & Book & Paper & Thickness & Colour & \multirow{6}{*}{$\begin{array}{c}\text { Table } 1 \\
\text { DATA FOR THE } \\
\text { SAMPLES } 1 A-5 A\end{array}$} \\
\hline $1 \mathrm{~A}$ & 1517 & $\begin{array}{l}\text { Herodianus, } \\
\text { Historica Libri VIII, Florence }\end{array}$ & $\begin{array}{l}\text { Handmade, rags fibres, no filigree, } \\
\text { horizontal water lines, gelatine size }\end{array}$ & $\begin{array}{l}0.095-0.12 \\
\mathrm{~mm}\end{array}$ & $\begin{array}{l}\text { Dark } \\
\text { yellow }\end{array}$ & \\
\hline $2 \mathrm{~A}$ & 1534 & Sophocles, Sophokleou, Haga & $\begin{array}{l}\text { Handmade, rags fibres, no filigree, } \\
\text { vertical water lines, gelatine size }\end{array}$ & $\begin{array}{l}0.095-0.12 \\
\mathrm{~mm}\end{array}$ & $\begin{array}{l}\text { Dark } \\
\text { yellow }\end{array}$ & \\
\hline $3 \mathrm{~A}$ & 1552 & $\begin{array}{l}\text { Amianus, De rebus gestis, } \\
\text { Lugduni (Lyon) }\end{array}$ & $\begin{array}{l}\text { Handmade, rags fibres, no filigree, } \\
\text { horizontal water lines, gelatine size }\end{array}$ & $\begin{array}{l}0.102-0.12 \\
\mathrm{~mm}\end{array}$ & $\begin{array}{l}\text { Dark } \\
\text { yellow }\end{array}$ & \\
\hline $4 A$ & 1587 & $\begin{array}{l}\text { Hennequin, J, Le Guidon } \\
\text { general, Paris }\end{array}$ & $\begin{array}{l}\text { Handmade, rags fibres, with filigree, } \\
\text { vertical water lines, gelatine size }\end{array}$ & $\begin{array}{l}0.102-0.12 \\
\mathrm{~mm}\end{array}$ & $\begin{array}{l}\text { Dark } \\
\text { yellow }\end{array}$ & \\
\hline $5 A$ & 1609 & $\begin{array}{l}\text { Biblia Sacra Vulgata Ed., } \\
\text { Lugduni (Lyon) }\end{array}$ & $\begin{array}{l}\text { Handmade, rags fibres, with filigree, } \\
\text { vertical water lines, gelatine size }\end{array}$ & $0.095-0.11$ & $\begin{array}{l}\text { Dark } \\
\text { yellow }\end{array}$ & \\
\hline
\end{tabular}




\begin{tabular}{|c|c|c|c|c|c|c|}
\hline Mode/Sample & $1 \mathrm{~A}$ & $2 \mathrm{~A}$ & $3 \mathrm{~A}$ & $4 A$ & $5 \mathrm{~A}$ & \\
\hline \multirow[t]{4}{*}{ O-H stretching [9] } & 3430 & 3410 & 3410 & 3410 & 3410 & \multirow{24}{*}{$\begin{array}{c}\text { Table } 2 \\
\text { WAVENUMBERS } \\
\text { OF PRINCIPAL } \\
\text { ABSORPTION } \\
\text { PEAKSAND } \\
\text { THEIR } \\
\text { ASSIGNMENTS }\end{array}$} \\
\hline & 3334 & 3331 & 3332 & 3334 & 3335 & \\
\hline & 3292 & 3293 & 3290 & 3288 & 3292 & \\
\hline & 3276 & 3279 & 3278 & 3285 & 3283 & \\
\hline \multirow{2}{*}{$\begin{array}{l}\text { C-H sym. stretching (methyl and } \\
\text { methylene) [10] }\end{array}$} & 2899 & 2899 & 2901 & 2915 & 2899 & \\
\hline & 2850 & 2872 & 2873 & $\begin{array}{l}2900 \\
2850\end{array}$ & $\begin{array}{l}2873 \\
2850\end{array}$ & \\
\hline Gelatine - amide I band [11] & 1648 & 1655 & 1648 & 1641 & 1643 & \\
\hline $\begin{array}{l}\mathrm{O}-\mathrm{H} \text { bending of absorbed water; ketone } \\
\mathrm{C}=\mathrm{O}[12]\end{array}$ & 1621 & 1630 & 1620 & 1632 & 1620 & \\
\hline Ca -carboxylate (stearate) & 1578 & - & - & 1578 & - & \\
\hline Gelatine - amide II band & 1546 & 1546 & 1547 & 1545 & 1551 & \\
\hline $\begin{array}{l}\mathrm{H}-\mathrm{C}-\mathrm{H} ; \mathrm{OCH} \text { in-plane bending vibration } / \\
\mathrm{CaCO}_{3}\end{array}$ & 1427 & 1426 & 1426 & 1427 & 1427 & \\
\hline $\mathrm{C}-\mathrm{H}$ in-plane bending & 1369 & 1370 & 1369 & 1370 & 1370 & \\
\hline S ring stretching [13] & 1334 & 1333 & 1334 & 1334 & 1334 & \\
\hline $\mathrm{CH}_{2}$ rocking vibration at $\mathrm{C} 6$ & 1314 & 1315 & 1315 & 1315 & 1315 & \\
\hline Lignin & $1280^{\circ}$ & $1280^{\circ}$ & 1280 & $1280^{\circ}$ & $1280^{\circ}$ & \\
\hline $\mathrm{C}-\mathrm{C}, \mathrm{C}-\mathrm{O}$ hemicellulose & 1247 & 1247 & 1247 & 1247 & 1247 & \\
\hline $\begin{array}{l}\text { C-O-C symmetric stretching, } \mathrm{OH} \text { plane } \\
\text { deformation }\end{array}$ & 1204 & 1204 & 1203 & 1204 & 1202 & \\
\hline $\mathrm{C}-\mathrm{O}-\mathrm{C}$ asymmetrical stretching & 1159 & 1160 & 1159 & 1161 & 1159 & \\
\hline Alum; non-symmetric in phase ring & 1108 & 1109 & 1109 & 1108 & 1109 & \\
\hline $\begin{array}{l}\mathrm{C}-\mathrm{C}, \mathrm{C}-\mathrm{OH}, \mathrm{C}-\mathrm{H} \text { ring and side group } \\
\text { vibration }\end{array}$ & $\begin{array}{l}1053 ; 1029 ; \\
994\end{array}$ & $\begin{array}{l}1053 ; \\
1030 ; 999\end{array}$ & $\begin{array}{l}1053 ; \\
1029 ; 999\end{array}$ & $1054 ; 1030 ; 1000$ & $\begin{array}{l}1054 ; 1030 ; \\
999\end{array}$ & \\
\hline Starch & $994 ; 983$ & $999 ; 984$ & $999 ; 984$ & $1000 ; 984$ & $999 ; 983$ & \\
\hline $\begin{array}{l}\mathrm{COC}, \mathrm{CCO} \text { and } \mathrm{CCH} \text { deformation } \\
\text { stretching [14] }\end{array}$ & 899 & 899 & 897 & 897 & 897 & \\
\hline $\mathrm{CaCO}_{3}[15]$ & 875 & - & - & 876 & - & \\
\hline $\mathrm{C}-\mathrm{OH}$ out of plane bending & 664 & 661 & 664 & 662 & 665 & \\
\hline
\end{tabular}

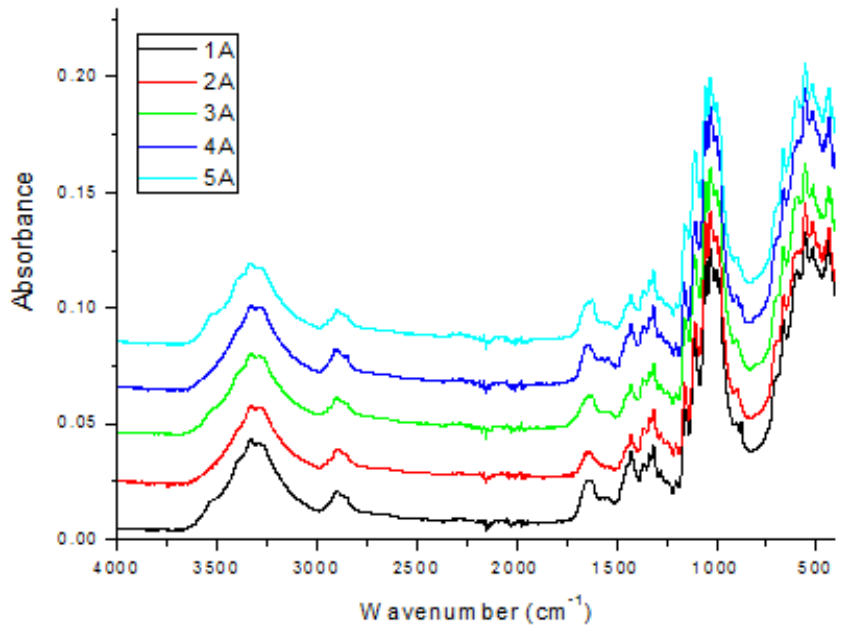

Fig. 2. The FTIR spectra for the samples $1 A-5 A$ (from bottom to top)

The hydrogen bond intensity ( $\mathrm{HBI}$ ) is in good correlation with crystalline system and intermolecular order degree, by measuring also the mobility of the polymeric chains and the length of the hydrogen bonds. The HBI can also be related with the trapped water molecules inside cellulose network. The ratio between intensity of the absorption bands from 3334 and $1314 \mathrm{~cm}^{-1}$ can be used to determine the $\mathrm{HBI}$ index.

Comparing values with those found in literature for cellulose from various origin our samples have lower values of $\mathrm{LOI}$ and $\mathrm{HBI}$, but higher values for $\mathrm{TCl}$ [19]. The lower values for $\mathrm{HBI}$ can indicate also a lower content of trapped water between cellulosic chains.

The well defined absorption bands from 1369, 1314 and $1247 \mathrm{~cm}^{-1}$ indicate the presence of non-tensioned cellulosic fibres, without polymeric chain dislocation along the fibre.

The energy and the length of hydrogen bonds can be calculated with equation 1 and 2:

$$
E_{H}=\left(v_{0}-v\right) / k v_{0}
$$

Table 3

THE VALUES OF TCI, LOI AND HBI CALCULATED FOR CELLULOSE

\begin{tabular}{|l|c|c|c|}
\hline Sample & \multicolumn{3}{|c|}{ IR crystallinity ratio } \\
\hline & $\begin{array}{c}\text { H1369/H2899 } \\
\text { (TCI) }\end{array}$ & $\begin{array}{c}\text { H1427/H899 } \\
\text { (LOI) }\end{array}$ & A3334/A1314 \\
\hline $1 \mathrm{~A}$ & 1.59 & 0.74 & 1.07 \\
\hline $2 \mathrm{~A}$ & 1.44 & 0.57 & 1.04 \\
\hline $3 \mathrm{~A}$ & 1.37 & 0.59 & 1.12 \\
\hline $4 \mathrm{~A}$ & 1.47 & 0.73 & 1.01 \\
\hline $5 \mathrm{~A}$ & 1.41 & 0.61 & 1.08 \\
\hline
\end{tabular}

where $v_{0}$ is the standard wavenumber of free hydroxyl moiety $\left(3650 \mathrm{~cm}^{-1}\right), v$ is the wavenumber measured for the specific hydroxyl moiety and $k$ is a constant $(1 / k=$ $2.625 \times 10^{2} \mathrm{~kJ}$ );

$$
\Delta v\left(\mathrm{~cm}^{-1}\right)=4430 \times(2.84-\mathrm{d}) \quad \Delta v=v_{0}-v
$$

where $v$ is the wavenumber of monomeric hydroxyl moiety $\left(3600 \mathrm{~cm}^{-1}\right)$, and $v$ is the measured wavenumber [19]. The energy and distances of hydrogen bonds for all five samples are presented in table 4.

The higher values for energy are associated with lower hydrogen bond distances, which mayin turn indicate higher interactions between intermolecular cellulose chains [16] .

The FTIR spectra for all samples have the amide I and II bands at about 1650 and $1545 \mathrm{~cm}^{-1}$ indicating the presence of animal gelatine. For the samples $1 A, 3 A$ and $5 A$ the band of 1650 is asymmetric, with another peak to $1620 \mathrm{~cm}^{-1}$, while for $2 \mathrm{~A}$ and $4 \mathrm{~A}$ the peak is at $1630 \mathrm{~cm}^{-1}$. The relative intensity of the amide absorption bands indicate that the lower gelatine content is found in sample $2 \mathrm{~A}$.

For samples $1 A$ and $4 A$ the FTIR spectra presents absorption a band at $875-876 \mathrm{~cm}^{-1}$ that indicate the presence of $\mathrm{CaCO}_{3}$ (either added on purpose at manufacture of the paper, or from hardness of the used water). Also for this two samples the absorption band from 
Table 4

THE CALCULATED ENERGY AND LENGTH FOR HYDROGEN BONDS IN CELLULOSE

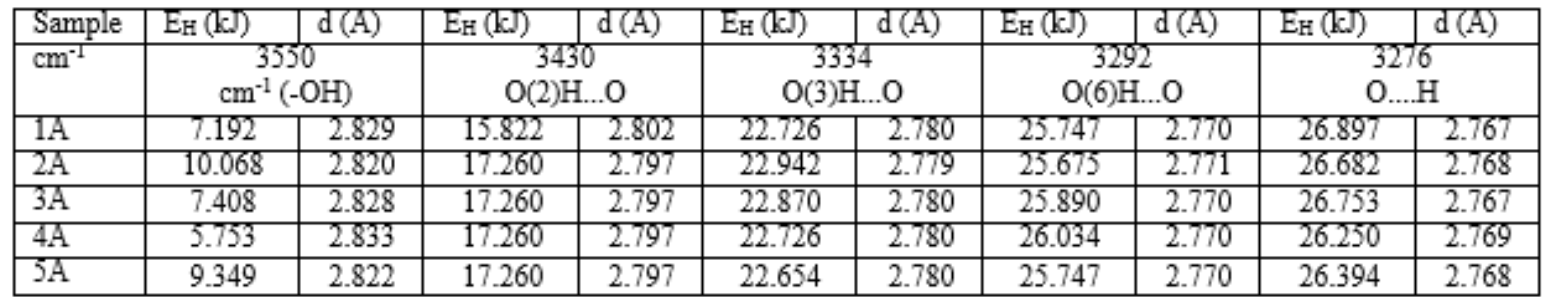

$1427 \mathrm{~cm}^{-1}$ is more intense, indicating the addition of peaks coming from $\mathrm{CaCO}_{3}$. For sample $1 \mathrm{~A}$ and $4 \mathrm{~A}$ there is also an absorption band at $1578 \mathrm{~cm}^{-1}$ indicating the presence of a calcium carboxylate (probably stearate from animal gelatine preparation) [20].

The electronic (UV-Vis) spectra recorded for $1 \mathrm{~A}-5 \mathrm{~A}$ samples are presented in figure 3 . All the recorded spectra have two absorption bands, with maxima at 222 and 328 $\mathrm{nm}$, but with different intensities due to variations in the used raw materials and differentstoring conditions. There is also visible a shoulder at $297 \mathrm{~nm}$ for all the sample. The relative high intensities of the UV bands from electronic spectra indicate that the species responsible for them in paper composition have conjugated double bonds since the single double bonds are not equally active [21]. They may arise from two possible electronic excitations $n \rightarrow \pi^{*}$ and $\pi \rightarrow \pi^{*}$. These can originate from both conjugated ketonic groups and their enolic forms [6]. The relative intensity 0 the $328 \mathrm{~nm}$ band vs. $222 \mathrm{~nm}$ band can indicate the degree of degradation of the paper sample (degradation index $I_{0}$ ). The $222 \mathrm{~nm}$ intensity stays relatively unchanged and the $328 \mathrm{~nm}$ increases with the degradation of cellulose [21]. Therefore, as I has higher values the cellulose has greater degree of degradation.

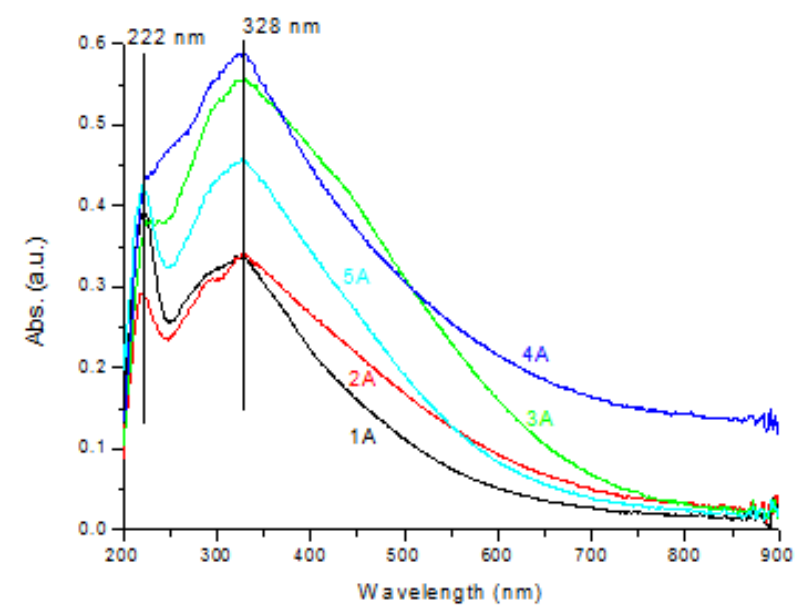

Fig. 3. Diffuse reflectance spectra for $1 A-5 A$ samples

Function of the type and quality of the used rags and the production method (water quality, hardness, retting time, quantity of used lime, even the quality of the workers) the paper sheet's colour was originally somewhere between white and light grey or yellow. The chemical changes that occur in paper with aging involve a multi-parameter process [6]. Over the centuries, the paper aged and the components were partially degraded, especially by acid hydrolysis, and the colour changed to dark yellow. Some aged papers develop stains in a process called foxing. The samples we analyzed were free of stains, with an uniform colour, various yellow shades. By measuring the area of the visible spectra in the blue-violet region (400-500 nm) we can quantify the shade of yellow from each sample. The yellowness of the samples was in good agreement with the $\mathrm{I}$ values, the most degraded sample being $3 \mathrm{~A}$ while the less degraded is $1 \mathrm{~A}$ (table 5).

Table 5

UV-Vis DATA FOR YELLOWNESS AND I VALUES

\begin{tabular}{|l|c|c|c|c|c|}
\hline Sample & $1 \mathrm{~A}$ & $2 \mathrm{~A}$ & $3 \mathrm{~A}$ & $4 \mathrm{~A}$ & $5 \mathrm{~A}$ \\
\hline Area 400-500nm & 16.26 & 21.70 & 39.69 & 37.24 & 26.70 \\
\hline $\begin{array}{l}\text { (ID) Intensity ratio } \\
328 \mathrm{~nm} / 222 \mathrm{~nm}\end{array}$ & 0.86 & 1.17 & 1.52 & 1.39 & 1.08 \\
\hline
\end{tabular}

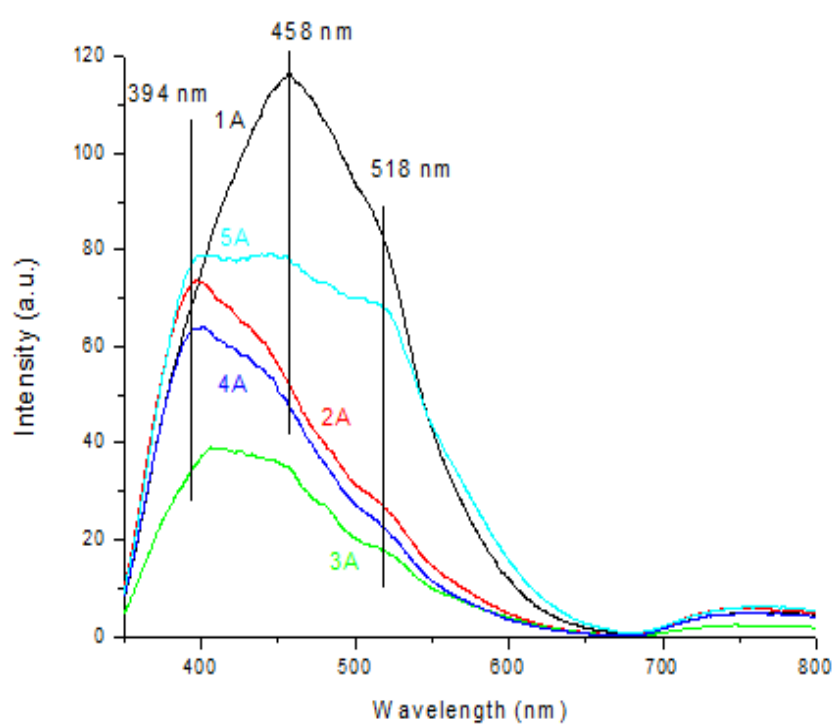

Fig. 4. Photoluminescence spectra for $1 A-5 A$ samples

The glycosidic bond cleavage is produced by the change in the hybridization of carbon C(2) and C(3) from $\mathrm{sp}^{3}$ to $\mathrm{sp}^{2}$ together with charge transfer from ketonic to enolic groups [21-23]

The $222 \mathrm{~nm}$ absorption band is partially produced also by the gelatine size of the paper [24]. On the sample 4A the absorption band from $222 \mathrm{~nm}$ is presented as a shoulder, which is an indication of modified gelatine, in concordance with FTIR spectra of that sample.

Molecular origin of fluorescence for the cellulose is not very well understood. The three most representative fluorophores were biphenyl, coniferyl alcohol, and stilbene, which may have various substituents. Even when lignin is removed, the cellulose still remain fluorescent and the carbohydrate components are the principal contributors to the total fluorescence the cellulosic papers. Phenols and quinonoid structures in cellulosic materials can also be counted among the source of the fluorescence. The presence of hemicellulose will also increase the fluorescence emission [25].

Another possibility is that fluorescent emission will originate from van der Waalls intermolecular interaction between cellulosic polymeric chains. This means that the greater crystallinity degree of cellulose, the more intense the fluorescence emission will be. The fluorescence intensity and wavelength of maximum emission are dependent on the origin and the processing of the cellulose. The oxidizing agents can diminish the intensity of fluorescent emission by producing carbonyl moieties. 
The deconvolution of fluorescence spectra for samples $1 \mathrm{~A}-5 \mathrm{~A}$ indicate the presence of at least three emission bands with maxima at $394 \mathrm{~m} 458$ and $518 \mathrm{~nm}$. The highest relative intensity is observed for the sample $1 \mathrm{~A}$, which contains the highest amount of crystalline cellulose. The sample 3A which contains the lowest amount of crystalline cellulose has also the smaller fluorescence emission. This is in agreement with the values calculated for TCl. Conjugated chromophores with diverse origin, even in small amounts, can collect the energy of photons from the cellulose matrix via an energy transfer process. This kind of mechanism will be favour by a higher crystallinity degree of cellulose.

Nevertheless the position of the fluorescence emission bands is not correlated with the origin of cellulose and the exact nature of the chemical structure of fluorophores in cellulosic remains an open question [25].

\section{Conclusions}

The present article underlines some specific spectral characteristics of early European manual paper samples. The spectral data can be correlated with the crystallinity degree of cellulose, which in turn is subject to origin and processing of textile fibres used to manufacture the paper. The overall storage conditions along centuries will also leave a mark on the papers properties. Crystallinity index, hydrogen bond intensity, yellowness degree and degradation parameters were calculated based on spectral data. All the spectral data and the calculated index can represent a fingerprint for a specific paper and therefore can be used further to identify unknown documents.

Acknowledgement: This work was supported by a grant of the Romanian Ministry of Research and Innovation, CCCDI - UEFISCDI, project number PN-III-P1-1.2-PCCDI-2017-0689 /P1. Lib2Life Revitalizarea bibliotecilor si a patrimoniului cultural prin tehnologii avansate within PNCDI II

\section{References}

1.BARRETT, T.D., The Paper Conservator, 13, 1989, p. 1.

2.BARRETT, T., ORMSBY, M., and LANG, J., Restaurator. International Journal for the Preservation of Library and Archival Material, 37(2), 2016, p. 93.

3.DABROWSKI, J. and SIMMONS, J.S.G., Fibres \& Textiles in Eastern Europe, 11(1), 2003, p. 8.

4.FAHY, C., Studies in Bibliography, 56, 2003-2004, p. 243.
5.VAJA, F., COMANESCU, C., OPREA, O., FICAI, D., GURAN, C., Rev. Chim. (Bucharest), 63, no. 7, 2012, p. 722.

6.AREA, M.C. and CHERADAME, H., Bioresources, 6(4), 2011, p. 5307. 7.UNSOY, G., GUNDUZ, U., OPREA, O., FICAI, D., SONMEZ, M., RADULESCU, M., ALEXIE, M., and FICAl, A., Current Topics in Medicinal Chemistry, 15(16), 2015, p. 1622.

8.GINGASU, D., OPREA, O., MINDRU, I., CULITA, D.C., PATRON, L., Digest Journal of Nanomaterials and Biostructures, 6(3), 2011, p. 1215.

9.GINGASU, D., MINDRU, I., CULITA, D.C., PATRON, L., CALDERONMORENO, J.M., PREDA, S., OPREA, O., OSICEANU, P., PINEDA, E.M., Materials Research Bulletin, 49, 2014, p. 151.

10.SENIN, R.M., ION, I., OPREA, O., VASILE, B., STOICA, R., GANEA, R., ION, A.C., Rev. Chim. (Bucharest), 69, no. 6, 2018, p. 1309.

11.LACATUSU, I., BADEA, N., MURARIU, A., OPREA, O., BOJ IN, D., MEGHEA, A., Soft Materials, 11(1), 2013, p. 75.

12.MIHALACHE, M., OPREA, O., GURAN, C., ARDELEAN, I.L., Rev. Chim. (Bucharest), 68, no.10, 2017, p. 2209.

13.SEGARCEANU, M., MIRON, A.R., LICA, C.G., OPREA, O., RIKABI, A.A.K.K., VAIREANU, D.I., Rev. Chim. (Bucharest), 69, no. 4, 2018, p. 772.

14.SENIN, R.M., ION, I., OPREA, O., STOICA, R., GANEA, R., ION, A.C., Rev. Chim. (Bucharest), 69, no. 5, 2018, p. 1233.

15.COVALIU, C.I., CHIOARU, L.C., CRACIUN, L., OPREA, O., and JITARU, I., Optoelectronics and Advanced Materials-Rapid Communications, 5(10), 2011, p. 1097.

16.POPESCU, M.C., POPESCU, C.M., LISA, G., and SAKATA, Y., J ournal of Molecular Structure, 988(1-3), 2011, p. 65.

17.AKERHOLM, M., HINTERSTOISSER, B., and SALMEN, L., Carbohydrate Research, 339(3), 2004, p. 569.

18.NELSON, M.L. and O'CONNOR, R.T., J. Appl. Polym. Sci., (8), 1964, p. 1311.

19.POLETTO, M., ORNAGHI, H.L., and ZATTERA, A.J ., Materials, 7(9), 2014, p. 6105.

20.LIBRANDO, V., MINNITI, Z., and LORUSSO, S., Conservation Science in Cultural Heritage, 11, 2011, p. 249.

21.LOJEWSKI, T., MISKOWIEC, P., MISSORI, M., LUBANSKA, A., PRONIEWICZ, L.M., and LOJ EWSKA, J., Carbohydrate Polymers, 82 (2), 2010, p. 370.

22.LOJEWSKI, T., ZIEBA, K., and LOJEWSKA, J., Journal of Chromatography A, 1217(42), 2010, p. 6462.

23.LOJ EW SKI, T., MISKOWIEC, P., MOLENDA, M., LUBANSKA, A., and LOJ EWSKA, J., Applied Physics a-Materials Science \& Processing, 100(3), 2010, p. 625.

24.DAS, M.P., SUGUNA, P.R., PRASAD, K., VIJAYLAKSHMI, J.V., and RENUKA, M., International J ournal of Pharmacy and Pharmaceutical Sciences, 9(9), 2017, p. 239.

25.CASTELLAN, A., RUGGIERO, R., FROLLINI, E., RAMOS, L.A., and CHIRAT, C., Holzforschung, 61(5), 2007, p. 504.

$\overline{\text { Manuscript received: } 19.12 .2018}$ 